\title{
Clinical case of diagnostics and treatment of acute fat hepatosis in pregnant
}

\author{
Kulbayeva Saltanat ${ }^{1}$, Akberdieva Gulmira ${ }^{1}$, Aldeshev Almas ${ }^{1}$, Junussova Raushan. ${ }^{1}$
}

${ }^{I}$ South Kazakhstan State Pharmaceutical Academy Shymkent, Kazakhstan

\section{УДК 616.361:617.053}

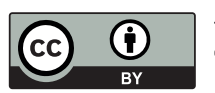

This work is licensed under a Creative Commons Attribution 4.0 International License

J CLIN MED KAZ 2017; 3(45 SUPPL 3):109-111 Автор для корреспонденции: Кулбаева С.Н., Южноказахстанская государственная фармацевтическая академия. Адрес: г. Шымкент, Казахстан. Телефон: 8-77252-40-82-22. E-mail: saltanat_phd@mail.ru

\section{ABSTRACT}

The article describes the clinical case of diagnosis of hepatosis in a pregnant woman, careful immediate delivery, and the use of prolonged veno-venous haemodiafiltration in complex pathogenetic therapy. This will significantly effectively stop the dysfunction of the hepatorenal and central nervous system with the correction of metabolic disorders.

Keywords: hepatosis of pregnant women, liver dystrophy of pregnant women, maternal and perinatal mortality.

\section{ЖҮКТІЛІК ЖӘНЕ ПРОТЕЙ СИНДРОМЫ ЖУКТІ ӘЙЕЛДЕ ЖЕДЕЛ БАУЫР ГЕПАТОЗЫН ДИАГНОСТИКАЛАУ ЖӘНЕ ЕМДЕУДІҢ КЛИНИКАЛЫҚ ЖАҒДАЙЫ \\ Кулбаева С.Н. ${ }^{1}$, Акбердиева Г.У. ${ }^{1}$, Алдешев А.А. ${ }^{1}$, Джунусова Р.К ${ }^{1}$. \\ 'Оңтүстік-қазақстан мемлекеттік фарацевтика академиясы, Шымкент, Қазақстан}

Мақалада жүкті әйелдегі жедел бауыр гепатозының диагностикасы, тез арада ұқыпты босандыру, сонымен қатар комплексті патогенетикалық терапияға қоса ұзартылған вено-венозды гемодиафильтрация сеансы терапиясын қолданудың клиникалық жағдайы сипатталған. Бұл метаболикалық бұзылыстарды қалпына келтірумен бірге, гепатореналды және орталық жүйке жүйесінің диссункциясын анағұрлым тиімді тоқтатуға мүмкіндік береді.

Маңызды сөздер: жүктілер гепатозы, жүктілер бауырының дистрофиясы, ана және перинаталды өлім

\section{КЛИНИЧЕСКИЙ СЛУЧАЙ ДИАГНОСТИКИ И ЛЕЧЕНИЯ ОСТРОГО ЖИРОВОГО ГЕПАТОЗА У БЕРЕМЕННОЙ}

Кулбаева С.Н. ${ }^{1}$, Акбердиева Г.У. ${ }^{1}$, Алдешев А.А. ${ }^{1}$, Джунусова Р.К. ${ }^{1}$

'Южно-казахстанская государственная фармацевтическая академия, г. Шымкент, Казахстан

В статье описан клинический случай диагностики гепатоза у беременной женщины, бережное незамедлительное родоразрешение, а также применение в комплексной патогенетической терапии сеансы продленной вено-венозной гемодиафильтрации. Это позволит значительно эффрективно купировать дисфункции гепаторенальной и центральной нервной системы с коррекцией метаболических нарушений.

Ключевые слова: гепатоз беременных, дистрофия печени беременных, материнская и перинатальная смертность.

\section{Введение}

Острый жировой гепатоз беременных (ОЖГБ) редко встречающееся тяжелое осложнение беременности, приводящее к высокой материнской и перинатальной смертности. Схожесть клинических проявлений ОЖГБ с различными инфекционными заболеваниями, редкость данной патологии обуславливает проблемы ее диагностики и лечения. Несмотря на внедрение в акушерскую практику новых методов диагностики, перинатальных технологий, расширения лабораторных возможностей, применение нового более эффективного арсенала препаратов для лечения данного осложнения, показатель материнской и перинатальной летальностей остается очень высоким, в связи с чем, проблему ОЖГБ можно считать актуальной.
Цель исследования: изучениеслучая ОЖГБв Областном перинатальном центре №1 г. Шымкент, особенностей клинического течения, трудностей, возникших при диагностике данного осложнения, а также эффективности применения в комплексной патогенетической терапии продленной вено-венозной гемодиафильтрации.

Материалы и методы исследования: нами проанализированы 1 случай ОЖГБ в областном перинатальном центре № 1 г. Шымкент за 2016 год.

\section{Клинический случай}

Беременная Б., 20 лет, поступила в ОПЦ №1 по направлению из ЦРБ 17.01.16 г. в 20ч. 10мин. с диагнозом: 1/1 беременность 39 недель 6 дней. 1 период родов. Дородовое излитие околоплодных вод (безводный период 14 
часов 10 мин). Холестаз беременных? Гепатоз беременных? Хронический недифференцированный гепатит? Асцит. Гестационная гипертензия. Умеренная анемия.

Анамнез жизни не отягощен. Данная беременность 1. 1-2 триместры беременности протекали на фоне умеренной анемии. Жалобы при поступлении на ежедневную тошноту, рвоту в течении одной недели, общую слабость, отеки на нижних конечностях в течение недели, схватки, отхождение околоплодных вод с 06 часов 00 минут 17.01.16 г. Из анамнеза заболевания:данная беременность 1. 1-2 триместры беременности протекали на фоне умеренной анемии. В течение последней недели отмечает ежедневную тошноту, рвоту до 2-3 раз в сутки, слабость, по поводу чего обращалась однократно в ЦРП, осмотрена терапевтом, записи нет. 17.01.2016 г. с утра отмечает ухудшение общего самочувствия, по поводу чего обратилась в ЦРБ, где проведено обследование (билирубин - 42,9 мкмоль/л). Осмотрена терапевтом: Берем. 39 недель. Гестационная гипертензия. Гепатоз беременных. Хронический недифференцированный гепатит? Проведена инфузионная и гипотензивная терапия. Учитывая вышеуказанный диагноз больная для дальнейшего обследования, лечения и родоразрешения направлена в ОПЦ №1.

Объективный статус при поступлении: состояние тяжелое, обусловлено печеночной дисфункцией. Сознание ясное, адекватное, очаговой мозговой симптоматики нет, склеры иктеричны, отмечается пастозность лица, на нижних конечностях и передней брюшной стенке выраженные отеки. АД 140/90 мм рт.ст. Живот мягкий безболезненный, увеличен за счет беременной матки. Печень, селезенка не пальпируются.

Врач приемного отделения выставляет вышеуказанный диагноз. Назначено полное клинико-биохимическое обследование (ОАК развернутый, ОАМ, моча на желчные пигменты, группа крови и резус фактор, биохимия, коагулограмма крови, моча на белок с повтором через 4 часа, суточная потеря белка, ИФА маркеры вирусного гепатита, УЗИ брюшной полости, ЭКГ, консультации терапевта, инфекциониста, гастроэнтеролога, окулиста). В анализах при поступлении: ОАК- Нb 105 г/л, эритроциты -3,5х1012/л; тромбоцитов - 210 х109 /л; лейкоцитов - 13,8х109/л; общий белок - 60 г/л, мочевина -5,2ммоль/л; креатинин- 80мкмоль/л, АлАТ - 1,5 моль/л, АсАТ-0,79моль/л; общий билирубин101,0мкмоль/л; прямой билирубин-57,6 мкмоль/л; непрямой билирубин-43,4 мкмоль/л.

Учитывая акушерскую ситуацию роды решено вести консервативно по партограмме с КТГ плода на фоне инфузионной, гипотензивной терапий и гепатопротекторов; при безводном периоде свыше 18 часов провести профилактику неонатального сепсиса-ампициллин по 2,0 гр.в/в каждые 6 часов до рождения ребенка, активное ведение 3-го периода родов.

17.01.16 г. 22 час 00 мин. жалобы остаются прежними. Общее состояние тяжелое, обусловлено печеночной дисфункцией. Головной боли нет, сознание ясное, зрение и слух не нарушены, в пространстве и во времени ориентируется, ЧСС 122 уд в мин, АД 130/90 мм ртст, температура тела 36,6 С, сатурация - $98 \%$. Схватки через каждые 3 мин по 40-45 сек, хорошей силы и продолжительности, сердцебиение плода до 160 уд/мин Диагноз: прежний. 1 период родов.

18.01.16 г. 01 час 45 мин самопроизвольные роды в срок живым доношенным плодом по шкале Апгар 5/7 баллов.
Учитывая тяжесть состояния, родильница через 2 часа после родов переведена в ОАРИТ.

Диагноз при переводе:

1/1 беременность 39 недель 6 дней. 1 самопроизвольные роды в затылочном предлежании. Холестаз беременных? Гепатоз беременных? Хронический недифференцированный гепатит? Вызванная беременностью гипертензия без значительной протеинурии. Асцит. Дородовое излитие околоплодных вод (безводный период 19 часов 45 мин). Умеренная анемия. В анализах: ОАК- Нb 103 г/л, эритроциты -3,42х1012/л; тромбоцитов - 205 х109 /л; биохимический анализ крови - общий белок - 60 г/л, мочевина -5,2ммоль/л; креатинин- 80мкмоль/л, АлАТ - 1,5 моль/л, АсАТ0,79моль/л; общий билирубин-101,0мкмоль/л; прямой билирубин-57,6 мкмоль/л; непрямой билирубин- 43,4 мкмоль/л. СРБ - 12,0. Коагулограмма: ПТИ - 20 сек- $80 \%$; фибриноген - 1,6 г/л ТВ-20 сек, АЧТВ-43 сек, МНО-1,3. ОАМ: белок-0,099г/л, желчные пигменты-отр. Выставляется средний риск тромбоэмболических осложнений. Начата антикоагулянтная терапия в профилактической дозировке по протоколу профилактики тромбозов; гипотензивная, гепотопротекторная, инфузионная терапии.

За время наблюдения и лечения в реанимационном отделении осмотрена:

- терапевтом: Гепатоз беременных. Хронический гепатит? Умеренная анемия.

- инфекционистом: данных за острый вирусный гепатит нет.

- хирургом: Хр.панкреатит в стадии обострения. Холестаз беременных. Хр. гепатит. ЖДА.

- невропатологом: Энцефалопатия.

-гастроэнтерологом: гепатоз неясной этиологии. Хр.вирусный гепатит?

- окулистом: ОИ-спокойные, среды прозрачные, глазное дно- ДЗН бледноватые, границы четкие, артерии сужены, вены-ход и калибр сосудов не изменен, сосудистый индекс 2:3, сетчатка бледно-розового цвета.

УЗИ брюшной полости (18.01.16): Гепатомегалия. Диффузные изменения в паренхиме печени и поджелудочной железе, селезенке, почек. Печень по типу гепатоза. Признаки холецистита. Выпот брюшной полости.

Повторно гастроэнтеролог после ФГДС: Хр. Язвенная болезнь. ДДНК с локализацией по задней стенке, больших размеров, болевой формой в активной фазе бульбит. Анализ крови на маркеры вирусных гепатитов (19.01.16) отрицательный.

В связи с ухудшением состояния родильницы, усугублением печеночной недостаточности (общий билирубин-123 мкмоль/л, прямой билирубин - 98 мкмоль/л, Нb65 г/л тромбоцитов-120,0х109/ /л) и присоединением почечной недостаточности (нарастание гипергидратационного синдрома, олигоанурии- темп диуреза до 20 мл/час на фоне стимуляции и нарастание азотистых шлаков: мочевина-10,6 ммоль/л, креатинин- 147 ммоль/л) начиная с 13-х суток после родов проведены 3 сеансагемодиафильтрации с целью детоксикации на фоне продолжающейся интенсивной гепато-, гастропротекторной, гипотензивной, антибактериальной, оксигенотерапий, мониторигажизненноважных показателей.

Улучшение общего состояния родильницы, клинических и лабораторных показателей (ОАК- $\mathrm{Hb86}$ г/л, эритроциты -3,12х1012/л; тромбоцитов - 265 х109 /л; биохимический анализ крови - общий белок - 59,7 г/л, 
мочевина -4,2ммоль/л; креатинин-77,4мкмоль/л, АлАТ - 1,5 моль/л, АсАТ-0,79моль/л; общий билирубин-25,4мкмоль/л. Коагулограмма: ПТИ - 17сек-94\%; фибриноген - 3,9 г/л ТВ-18 сек, АЧТВ-26 сек, МНО-1,1. ОАМ: белок-0,033г/л) наступило на 20 - сутки послеродового периода. Для дальнейшего наблюдения и реабилитации согласно приказа № 595-0 переводится в ЦРБ.

\section{Результаты и обсуждение}

В вышеописанном клиническом случаях наибольшие трудности возникали при дифференциальной диагностике ОЖГБ и острых вирусных гепатитов (ОВГ). По данным В.Н. Кузьмина, Л.В. Адамян [2] появлению желтухи при ОЖГБ во всех случаях предшествует дожелтушная стадия. Эта стадия во всех случаях характеризуется наличием гестоза, а также развитием диспепсических расстройств в виде тошноты, рвоты, болей в области желудка, усиливающейся выраженной изжоги, в результате которой может возникать рвота с примесью гематина («кофейной гущи»). У данной беременной явления гепатоза сопровождались печеночной недостаточности и признаками ДВС синдрома.

По данным литературы [2] существенным звеном патогенезаОЖГБявляетсяДВСсиндром,которыйразвивается уже на ранних стадиях заболевания. Во многих случаях
ДВС синдром является причиной тяжелых осложнений, что может привести к внутриутробной гибели плода и к гибели женщины от коагулопатического кровотечения. В данном клиническом случае диагностика жировой дистрофии печени была проведена с минимальнойпотерей времени, что позволило выбрать правильную этиопатогенетическую тактику ведения беременной, лечения данной патологии и получить более успешный исход как для матери, так и для плода.

\section{Выводы}

Таким образом, учитывая наличие трудностей в дифференциальной диагностике ОЖГБ с другими заболеваниями, в частности с ОВГ, считаем наиболее важным своевременную быструю диагностику гепатоза, бережное незамедлительное родоразрешение, а также применение в комплексной патогенетической терапии ОЖГ сеанов продленной вено-венозной гемодиафильтрации, что позволит значительно эффективно купировать дисфункции гепаторенальной и центральной нервной системы с коррекцией метаболических нарушений, снизить частоту акушерских осложнений, показателей материнской и перинатальной заболеваемости и смертности.

\section{Литература:}

1. Shehtman M.M. Rukovodstvo po jekstragenital'noj patologii u beremennyh (Manual on extragenital pathology in pregnant women) [in Russian]. M.: Triada - H; 2005:268-271 p.

2. Kuz'min V.N., Adamjan L.V. Varianty klinicheskogo techenija, diagnostiki i lechebnaja taktika ostrogo zhirovogo gepatoza beremennyh (Variants of clinical course, diagnostics and therapeutic tactics of acute fatty hepatosis of pregnant women) [in Russian]. Akusherstvo i ginekologija. 2009:25-29.

3. Aimbetova A.R., Bazylbekova Z.O., Biktasheva H.M., Vashhenko V.M. i dr. Beremennost' i jekstragenital'nye zabolevanija (Pregnancy and extragenital diseases) [in Russian]. Almaty.2013:165-197, 375-397.

4. Aldeshev A.A., Kokenova M.U., Rezhametov D.P., Mamaev S.R., Kadirhanov A.Z. Ispol'zovanie prodlennoj veno-venoznoj gemodiafil'tracii v akusherskoj praktike (Use of prolonged veno-venous hemodiafiltration in obstetric practice) [in Russian]. Aktual'nye voprosy akusherstva, ginekologii i perinatologi zhurnal-sbornik. 2015; 2(3-4): 96-98.

5. Jushhuk N. D., Kuz'min V. N., Malyshev N. A. Ostryj zhirovoj gepatoz v infekcionnoj i akusherskoj praktike (Acute fatty hepatosis in infectious and obstetric practice) [in Russian]. Klinicheskaja medicina. 2002;10(9): 51-56.

6. Kuz'min V.N., Serobjan A.G. Ostryj zhirovoj gepatoz beremennyh v praktike akushera-ginekologa (Acute fatty hepatosis of pregnant women in the practice of obstetrician-gynecologist) [in Russian]. Lechashhij vrach. 2005; 3(4):25-29. 